\title{
Owning the lake, not just the rod: The continuing challenge of 'the old boys' in knowledge production
}

AUTHORS:

Mwazvita T.B. Dalu ${ }^{1}$

Ashley W. Gunter ${ }^{1}$

Ryan J. Wasserman²

Tatenda Dalu ${ }^{3}$

\section{AFFILIATIONS:}

'Department of Geography,

University of South Africa,

Pretoria, South Africa

${ }^{2}$ School of Science,

Monash University Malaysia,

Bandar Sunway, Malaysia

${ }^{3}$ Department of Ecology

and Resource Management,

University of Venda,

Thohoyandou, South Africa

\section{CORRESPONDENCE TO: \\ Mwazvita Dalu}

\section{EMAIL:}

smazvita@gmail.com

\section{KEYWORDS:}

Africa; decolonisation; development; policy; research; scientific publications

\section{HOW TO CITE:}

Dalu MTB, Gunter AW,

Wasserman RJ, Dalu T. Owning the lake, not just the rod: The continuing challenge of 'the old boys' in knowledge production. S Afr J Sci. 2018;114(7/8), Art. \#a0275, 2 pages. http://dx.doi org/10.17159/sajs.2018/a0275

\section{PUBLISHED:}

30 July 2018

(C) 2018. The Author(s). Published under a Creative Commons Attribution Licence.
Knowledge from the Global South, and particularly Africa, is continuously exported and repackaged, thereby transferring its ownership to those able to conform it to the paradigms of consumption in the knowledge economy of the Global North. The list of the top 40 scientific papers by country, according to Scopus, reflects a significant under-representation of publications from Africa. It is significant to note that only one African country - South Africa - features on the list, but only in the bottom five journals. ${ }^{1}$ This exclusion may be for many reasons, not withstanding those related to funding and government support, the developmental needs of universities, a lack of ability on the part of the authors themselves to write to Western paradigms and standards, and the career aspirations and needs of African academics. Yet we propose that these issues are not the only reasons for the lack of academic voice from the African continent - there is a substantial amount of research on inequality in global knowledge production which largely focuses on income and resource inequality as the major reason for this situation. ${ }^{2-4}$ It is, however, arguable that focusing only on the technical and economic limitations of African academics, whilst ignoring the greater cultural and political context within which the practice of academia is in itself deeply entrenched, does not sufficiently account for the challenges that they face. However, a significant cause of academic silence is the consequence of barriers resulting from practices of 'the old boys' network'. Thus, focusing on the global publication practices in academia, we present fresh arguments to bring to centre stage the consequence of barriers resulting from these networks. Here, the relative socio-political challenges of African academics are critically interwoven into the understanding and functioning of the informal old boys' network.

The idea of the 'old boys' network' stems from the British elite school system in which men of influence and means used their status to advance other men from the same school. There is much literature on the 'old boys' network' in numerous sectors. Yet this concept is still elusive and vague and few would openly acknowledge being part of any network that propagates the advancement of individuals from a similar social background. The developmental implications thereof, especially in light of the current prioritisation of the decolonisation agenda in South Africa, are also therefore discussed.

It could equally be argued that the idea of 'the old boys' may simply be a consequence of Western academia being the historical core of the university system and, as such, certain academics have mastered the paradigms, systems and language through many cycles of evolution and refinement. However, the oldest university (University of al-Qarawiyyin, Fez) is located in Morocco - on the African continent. ${ }^{5}$ This raises the question of why similar cycles of evolution and refinement have not taken place within the African science and higher education context, leading to Morocco's influence within science and education among the ranks of world-leading scientific outputs. This may critically show that "contemporary social, political, economic and cultural practices continue to be located within the processes of cultural domination through the imposition of imperial structures of power' 6 . The systems of academic ratings, credible outputs, journal listings and publication status is set, monitored and regulated almost exclusively by individuals based in the Global North. ${ }^{7,8}$

The idea of monopolies of power with regard to who actually moderates academic outputs, including journal publications, points to a centre of gatekeeping in the Global North. By consistently maintaining the reins on determining what is accepted, rejected or simply unpublishable, the old boys' network continues to hold up barriers to prominence on the global knowledge economy by African academics and institutions. The historical legacy of imperialism and colonialism is widely recognised as a barrier to development in Africa, and yet within the knowledge economy little has been done to redress the problems that this former system has left. While inferior education was forced upon Africans during the colonial era, ${ }^{9}$ it is more apparent in some nations (e.g. South Africa) than in others (e.g. Zimbabwe). As the countries similar to the latter conformed to the 'colonial master's' standards in their general and academic culture, they seem to fair slightly better on the international academic arena, which is governed largely by the old boys' network. Similar situations likely ensue in other parts of the world where regions are currently geographically or politically fragmented as a result of the legacy of colonialism.

Although many colonial inequalities have since been redressed in most African countries to some extent, the stains of the colonial legacy still seem to manifest in the international publishing arena, as a form of mistrust by editors to African authors affiliated with African academic institutions. It appears that all knowledge is often evaluated against 'expert' knowledge based on Western scientific paradigms, before it is considered valid and useful, even to a nonWestern context. This mistrust expresses itself through various means, such as intense and vigorous checks of native African writing or even the writing of authors of European descent who are affiliated with an African academic institution..$^{10}$ To date, European languages remain the languages of power, in spite of the many developments of local journals within the Global South. Thus, the colonial experience inherently continues to shape and influence research and its representation within the reproduction of knowledge in publications. As such, more native African academics come across more negative comments centred on language issues from reviewers, in comparison to their Northern counterparts. According to Sithole ${ }^{11}$, the environment in the Global North for the African scholar is hostile, and is made insecure because, somehow, the African scholar is assumed to need the tutelage even of the most junior scholars from the Global North and it is assumed that their facts (even those originating from the more familiar local Global South context to the scholar) must be checked. This experience is also shared by academics of European descent who are based at African institutions, although to a lesser extent. ${ }^{12}$

One also gets a sense that patronage exists in the selection of a reviewer, as typically with some journals, the editor selects reviewers from an existing pool of members of a journal's board. Thus, very often, African authors must 
face up to reviewers who are of North American or European descent, many of who (although well-meaning) harbour a bias towards Northern research interests where most journals of international accreditation are based. ${ }^{13}$ This bias is often further exacerbated by the additional criterion of assigning reviewership and editorship to what, or rather who, constitutes an 'authoritative voice' within a certain area of research within the Global South, having been systematically determined by the old boys themselves. The latter paradox seems to have resulted in the monopoly of certain research areas to be associated with northern institutions or non-African scholars based at these institutions, in spite of an African scholar appearing to be in a more credible contextual position to conduct more comprehensive research. It has been argued that African scholarship needs to be synergistically organised and applied to subject matters and fields in which African scholars have a comparative advantage..$^{14}$ This argument, however, is gravely challenged by the old boys' network, as often the Global North tends to be responsible for conception, while the Global South is involved merely in the execution of tasks (e.g. data collection and field experiments), thus facilitating their limited inclusion in knowledge packaging and ownership of the knowledge market in publishing. ${ }^{15,16} \mathrm{An}$ example is that of large charismatic African wildlife species research (e.g. large mammals), which attracts much media attention and funding, yet publications thereon and grants for research continue to greatly exclude native African scholars, particularly in prominent positions within research projects. Even in cases in which African scholars appear to have prominent research positions in these areas, some of our intellectuals may be merely figure heads. These same scholars are constantly faced with the danger of alignment with whoever is paying for knowledge, as many funders are more favourable to scholars publishing in Global North journals, which often aim to fulfil Northern research interests. Thus, local scholars cease to sufficiently address the research needs and interests of the locality of origin, with detrimental implications to the development of the Global South.

Even African rating systems perpetuate the dominance of the old boys' network, by holding journals based in the Global North to a higher esteem than those based in the local Global South. For example, the system in South Africa will rank a local scientist with more publications in journals of Global North origin (which also, consequentially, usually have the higher impact factor), higher than those whose publications are mostly in local journals of Global South origin (http://www.nrf.ac.za/rating). Thus, higher knowledge exchange, and quality of thought, occurs between the Global North and South in comparison to that which occurs within the Global South exclusively. This situation has facilitated the 'lack of and/or poor development of internal scientific discussions and debates within and between our scientific communities, resulting in a general stampede of Global South scholars for individual acknowledgment by the Global North'14. Thus, although not intentional, these actions continue to actively facilitate the Global North in dominating policy development and implementation in the local sphere. Should scientific knowledge indeed inform policy, then the Global North continues to reinforce its power over the Global South, through dictating which or what knowledge is considered 'good', thereby presenting a significant challenge to the decolonisation agenda within policy, development and education in the Global South. Sithole ${ }^{11}$ quotes Karioki as pointing out that 'Africa demands of its intellectuals to serve the communities from which they spring'. Hence, the Western saying 'give a man a fish, and feed him for one day; give him a rod, feed him for a lifetime', warrants an African revision: redress rightful entitlement to own the lake within which they fish, and you empower a continent.

\section{Acknowledgements}

Any opinions, findings, conclusions or recommendations expressed in this material are those of the authors, and the University of South Africa, Monash University Malaysia and University of Venda do not accept any liability in this regard.

\section{References}

1. Organisation for Economic Co-operation and Development (OECD). OECD science, technology and industry scoreboard 2017: The digital transformation. Paris: OECD Publishing; 2017.

2. Kapungu RS. The pursuit of higher education in Zimbabwe: A futile effort?' A paper prepared for the Center for International Private Enterprise (CIPE) 2007 international essay competition on 'Educational reform and employment opportunities' [document on the Internet]. c2007 [cited 2017 Oct 25]. Available from: http://archive.kubatana.net/docs/chiyou/kapungu_cipe_ essay_higher_education_071002.pdf

3. Aarts $H$, Greijn H. Globalization, knowledge and learning: Developing the capacities of higher education institutes. In: Teferra D, Greijn H, editors. Higher education and globalisation - Challenges, threats and opportunities for Africa. Maastricht: Maastricht University Centre for International Cooperation in Academic Development (MUND0); 2010. p. 9-18.

4. Hwami M. 'The Nativist Turn' and the crisis in university education. Int J Educ. 2013;5(4):124-144. https://doi.org/10.5296/ije.v5i4.4480

5. Verger J. Patterns. In: De Ridder-Symoens $H$, editor. A history of the university in Europe volume I: Universities in the Middle Ages. Cambridge, UK: Cambridge University Press; 2003.

6. Madge C, Raghuram P, Noxolo P. Engaged pedagogy and responsibility: A postcolonial analysis of international students. Geoforum. 2009;40:34-45. https://doi.org/10.1016/j.geoforum.2008.01.008

7. Jöns $H$, Hoyler M. Global geographies of higher education: The perspective of world university rankings. Geoforum. 2013;46:45-59. https://doi. org/10.1016/j.geoforum.2012.12.014

8. Liu NC. The story of academic ranking of world universities. Int Higher Educ. 2015;54:2-3. https://doi.org/10.6017/ihe.2009.54.8409

9. Maringe $F$, Ojo E. Sustainable transformation in a rapidly globalizing and decolonising world. In: Maringe F, Ojo E, editors. Sustainable transformation in African higher education. Rotterdam: Sense Publishers; 2017. p. 25-39. https://doi.org/10.1007/978-94-6300-902-7_2

10. Morita N. Negotiating participation and identity in second language academic communities. Tesol Q. 2004;38:573-603. https://doi.org/10.2307/3588281

11. Sithole MP. Unequal peers: The politics of discourse management in the social sciences. Pretoria: Africa Institute of South Africa; 2009.

12. Edmondson R, Luhtakallio E. Writing sociology, publishing sociology. Euro J Cultur Polit Sociol. 2016;3:387-391. https://doi.org/10.1080/23254823. 2016.1245244

13. Czerniewicz L. Inequitable power dynamics of global knowledge production and exchange must be confronted head on. LSE Blog. 2013 April 29 [cited 2017 Jun 28]. Available from: http://blogs.lse.ac.uk/ impactofsocialsciences/2013/04/29/redrawing-the-map-from-access-toparticipation/

14. Sithole B. My knowledge, your knowledge, whose knowledge is it? Reflections from a researcher's journey through universities in North and South. In: Adriansen HK, Madsen LM, Jenses S, editors. Higher education and capacity building in Africa: The geography and power of knowledge under changing conditions. Oxfordshire: Routledge; 2016.

15. Adriansen HK, Madsen LM, Jenses S, editors. Higher education and capacity building in Africa: The geography and power of knowledge under changing conditions. Oxfordshire: Routledge; 2016.

16. Muller J, Cloete N, Van Schalkwyk F, editors. Castells in Africa: Universities and development. Cape Town: African Minds; 2017. 